\title{
く屯膜暿室による胸椎部ミエロパチー例について
}

\begin{tabular}{|c|c|c|c|c|c|c|}
\hline 山 & $\square$ & 芳 & $\begin{array}{l}\text { 教至（主作 } \text { 英・服 }\end{array}$ & 部 & & 奖 \\
\hline 小 & 山 & 正 & 信・早 & 川 & & 宏 \\
\hline 礒 & 部 & 輝 & 雄 - 吉 & 田 & 義 & 夫 \\
\hline 桜 & 田 & 和 & 之 & & & \\
\hline
\end{tabular}

\section{Spinal Arachnoid Diverticula with Neurological Impairment in the Lower Limbs.}

by

\author{
Y. Yamaguchi, S. Hattori, M. Oyama, H. Hayakawa, \\ T. Isobe, Y. Yoshida, and K. Sakurada \\ Department of Orthopedic Surgery, Yamaguchi University \\ School of Medicine. Ube-City, Japan.
}

(Director: Prof. Susumu Hattori)

\begin{abstract}
This paper reports two cases of spinal arachnoid diverticula with neurological impairment in the lower limbs.

Case 1. 50 years-old female had weakness of right lower limb and gait disturbance for 20 years. She was hospitalized in our clinic because of gradually progressive neurological impairment in the lower limbs. At admission she had spastic paresis and hyperactive tendon reflex of the lower limbs, gait disturbance, sensory disturbance below the level of T4 and muscle atrophy of the right lower limb. On myelography with the patient prone, there was no evidence of obstruction but in the supine position, five ovoid stractures filled with myodil at the level of T6-T11 were seen. These were defined sharply in the upright position. Laminectomy from the 6th to 11 th thoracic vertebraes was carried out. The arachnoid looked thin, muddy and mesh formed, and was filled with colorless fluid and myodil. The abnormal arachnoid were resected as extensive as possible. Gait disturbance and paresthesia improved gradually in 6 months after operation.

Case 2. 55 years-old female has complained of back pain and weakness of both lower limbs for 10 years. The only neurological finding was hyperactive knee jerk on both sides and hyperactive ankle jerk on the right side. On myelography with the patient supine, two ovoid structures filled with myodil at the level of T3-4 and T4-5. Because of poor neurological sign, she was treated conservatively and the neurological signs have been observed.
\end{abstract}

\section{はじめに}

脊䯣くも膜稳室は 1909 年に Bliss が Cyst of the Spinal Cord として報告したのが最初であり，一般 的には神経症状を伴うことは稀であるが，てれまで神 経症状を伴った報告例は外国で 30 数例，本邦では 10
数例にすぎない，最近私達は脊䯣くも膜秝室が原因と 思われる胸椎部ミエロパチー2 例を経験したので報告 する.

症例

症例 1：】50才, 女子, 事務員 


\section{主 訴：右下肢脱力感，歩行障害}

現病歴：約 20 年前より誘因なく右下肢の脱力感之 右下肢をひきづるような歩行を呈する. 4 ～5 年前よ り歩行障害は徐々に增強し痙性となり, $200 \mathrm{~mm}$ 位の 歩行で足がもつれ歩行不能となる. 某病院に入院し, ミエログラフィーを行なうむ異常なく，保存的加療で あ軽快しないため，当科を紹介される．上肢の運動・ 排尿障害はないが，10 年前より 便秘がちで緩下剂を 服用している。

既往歴：胃潰瘍で保存的加療（昭和 51 年 4 月〜 6 月)

家族歴：特記すべきことなし．

入院時所見: 体格中等度, 栄養良好, 胸椎は $\mathrm{Th}_{6}$ を中心に円背を呈し，右下肢に筋萎縮を認奷＼cjkend，筋力は 3 4 - 右膝関節の自動運動はぎこちなく，右足関節 の背屈が十分できない. PTR. ATR は両側穴進（右 $>$ 左), Babinski は右 $(+)$, 左 $(-)$, 歩行は右は 痙性で下垂足を呈し, 歩行能力は $200 \mathrm{~m}$ 位. 片脚起 立は右は不能で, 知覚障害は $\mathrm{Th}_{4}$ 以下に軽度の知覚 鈍麻をみる（図 1)。

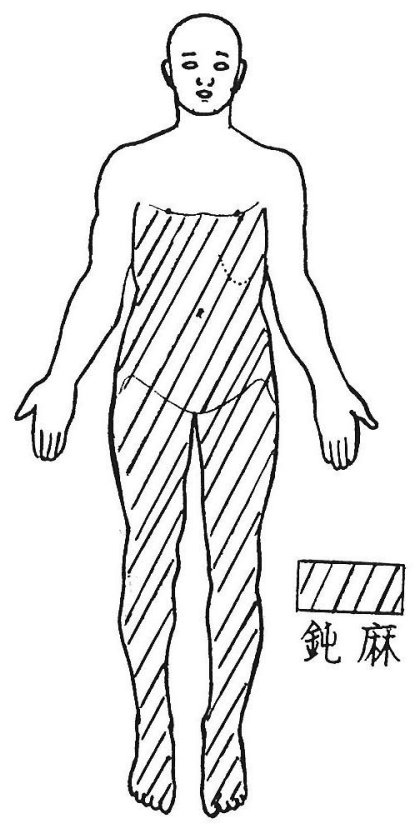

図 $1 \mathrm{Th}_{4}$ 以下触・痛党鈍麻

単純レ線：軽度の脊椎症性変化あり.

一般血液検查：貧血以外異常なし.
脳春䯇液検查：水様透明, Queckenstedt $(-)$ 蛋白 $38 \mathrm{mg} / \mathrm{dl}$ ，細胞数 $4 / 3$

筋電図: Neurogenic Muscle Atrophy.

膀胱内圧測定：神経因性膀胱

前脊揈動脈撮影：異常なし.

ミエログラフィー：マイオジール $15 \mathrm{ml}$ 使用，胸 椎部には初回のミエログラフィーでは通過障害を認め ず, Delayed Myelography にて $\mathrm{Th}_{6} \sim \mathrm{Th}_{11}$ の範 囲で脊䯣の後方に 5 個のポケット状の造影剂の停留像 を認め，立位にするとその像はシャープとなる（図

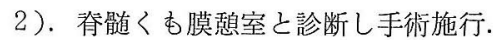
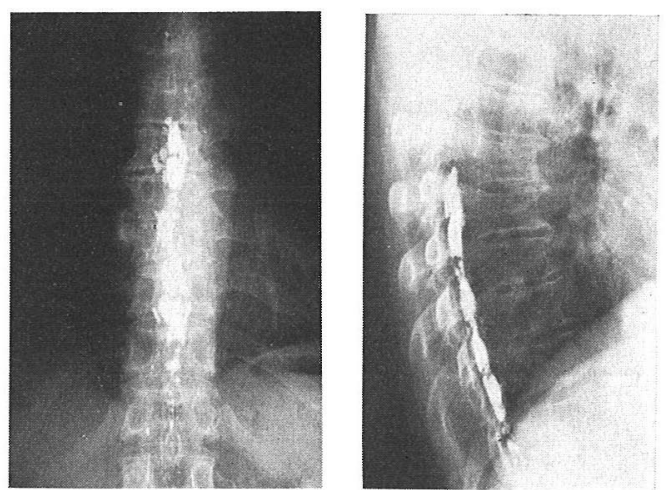

図2 $\mathrm{Th}_{6} \sim \mathrm{Th}_{11}$ に5 個のポケット状の 造影剤の停留像（仰臥位）

手術所見：硬膜外腔に 異常なく，硬膜を 切開する と，くも膜は白濁した網状を呈し，乙の組織は脊䯣液 が流失すると脊䯣に密着して不明瞭となるが，麻醉バ ッグの加圧により春䯣液が 流れ込むと多房性に膨満 し，その中に造影剂の油滴が透見される。乙れを可及 的に切除したが，春䯣の圧痕は認めない。

病理組織所見：線維性に肥厚し，好中球の浸潤が中 等度にみられるくも膜組織（図 3 ).

術後経過：術後 3 週よりコルセットをつけて歩行開 始. 術後 4 週には知覚障害, 右下肢の脱力感は消失, 術後 8 週には右下垂足は消失し, 痤性歩行严改善, 術 後ミエログラフィーではポケット状の造影剤の停留像 なし. 現在術後 6 力月であるが，右下肢の菱縮，腱反 射の六進を認ぬるが，下肢の運動・知覚障害は改善し ている.

症例 2, 55 才, 女性, 農業

主 訴：背部痛，両下肢脱力感

現病歴：約 10 年前より誘因なく背部痛，両下肢脱 


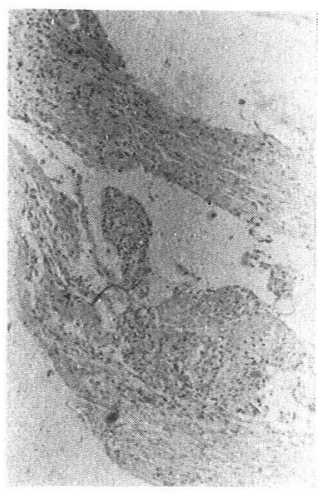

$\times 20$

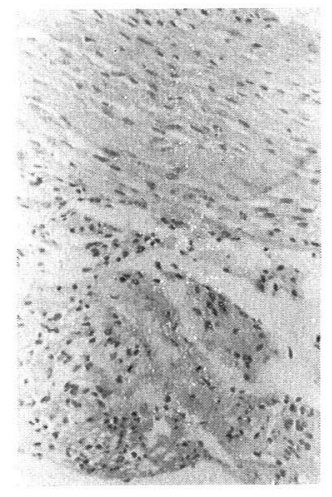

$\times 100$
図 3 肥厚と好中球の浸潤むり

力感をきたす. 背部痛は徐々に増強し, 特に立位, 仰 臥位で強く, 側臥位で軽快するが, 歩行障害, 直晹膀 胱障害は認めない。

既往歷：高血圧で加療中.

家族歴：特記すべきととなし．

初猃時所見：体格中等度，栄養良好， $\mathrm{Th}_{6}$ を中心 に円背を呈するが, 可動性良好, $\mathrm{Th}_{3} \sim \mathrm{Th}_{5}$ の棘突起 に吒打痛あり。両下肢の運動障害, 筋萎縮を認めな い. 歩行 - 知覚之も飞正常. PTR 両側元進, ATR 右六進, 左正常, 病的反射 (-).

脳脊䯣液検查: 水㥞透明, Queckenstedt $( \pm)$

蛋白 $107 \mathrm{mg} / \mathrm{dl} \quad$ 細胞数 $2 / 3$

単純レ線：軽度の脊椎症性変化

ミエログラフィー：腹臥位では通過障害を認めない
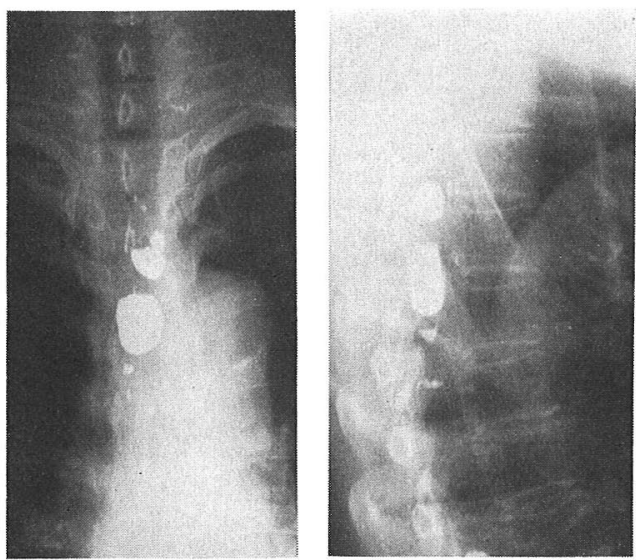

図4 $\mathrm{Th}_{3-4}, \mathrm{Th}_{4-5}$ にポケット状の造影剤の停 留像 (仰卧位)
が，仰臥位では $\mathrm{Th}_{3-4}, \mathrm{Th}_{4-5}$ の脊䯣後方にポケット 状の造影剂の停留像を認め, 立位にするとその像はシ ャープとなる（図 4). 本例は症状が軽いため, 保存 的加療にて経過観察中である.

考察

脊咀くも膜頽室は 1909 年に Bliss が Cyst of the Spinal Cord として報告したのが最初であるが， 統 一された命名がなく Leptomeningeal Cyst, Intradural Cyst, Locarised Adhesive Spinal Arachnoiditis などと呼ばれていたが, 1966 年 Paul Teng は解剖学的に真の Cystでないととから Spinal Arachnoid Diverticula と命名して以来, この名称 が使用されるようになった，その頻度は Teng によ れば腰椎のミエログラフィーを行った 97 例中 44 例に 胸椎部に敗室を認め, 稀でないとのべ, 立位でミエロ グラフィーを行なうととを奨めているが, 私達の経験 ではそ机ほど多いようには思わ饥ず，さらに神経症状 を呈するすのは少ないようである．乙れまでの報告例 を要約すると 40 才代に多く, 女子は男子の 2 倍で, 発生高位は胸椎中部が多く, 占拠横断部位はほとんぞ が脊檤の後方で, 多発性のものが多く, 単発性でも憙 室が大きい場合には神経症状を呈している. 私達の症 例もほぼこの特徵を満足している. 臨床症状は脊䯣腫 瘍に類似し, 背部痛または放散痛, 知覚異常, 下肢の

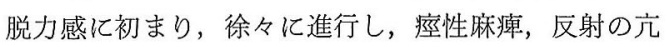
進, 歩行障害, 直腸膀脱障害をきたすようになる。乙 れらの症状は立位で増悪し臥位で軽快すると言わ机て いるが，症例 1 は病歷が長いせいかてのような所見は 認めなかった，神原らは症状が立位で增悪, 卧位で寛 解するものを Transient Type, 立位・卧位関係 ないものを Constant Type と分類しているが, そ れによると症例 1 は Constant type, 症例 2 は Transient Type である. 単純 X-P では異常所見 を示さないととが多いと言われているが，私達の症例 は2 例と屯軽度の脊椎症性变化がみられた。脳脊䯣液 検查では異常を認めないととが多いが, 稀に通過障害 や蛋白の増加を示すことがあり, 症例 2 で異常をみ た. 本症の確定診断にはミエログラフィーは必須で, 腹臥位では所見がなく，仰臥位より立位にすると造影 剂が䄸室に流入しポケット状の停留像を示すのが特徵 的であるが，Teng 等によると初回のミエログラフィ 一では見逃されることが多く，また本症には Sacral 
Perineural Cyste を合併（12 例中 6例に）している ことが多いので腰仙部を含めた Delayed Myelography を奖めている. 病因については確立されたも のはないが, Donald 等は外傷後の炎症性反応が㮩室 を形成すると推論しているが, Teng 等は切除したく あ膜の組織検査で炎症反応がみられないととや手術時 の所見よりくあ膜梁（後中隔）の分布異常があって, そてに外傷や小出血が加わって生じたものではないか 之推定している. 神経症状の発現に関しては Teng 等は立位で増悪し臥位で寛解することより㖪液の重量 による脊髄產引説を唱えている．Donald や杉本等は 秝室が大きい場合，手術時に脊髄の圧迫所見がみられ たてとより脊髄圧迫説を唱えている，治療法としては Transient Type は保存的に, 症状が進行性で, 保 存的加療で 軽快 せず, 頽室が大きくて多発性で, Constant type のものには咊室の切除が必要である.

\section{結語}

脊䯣症状を呈した脊䯣くも膜咊室 2 例を経験し， 1 例は手術的治療を行ない良好なる結果を得たが，1例 は保存的治療で経過観察中である. 胸椎部ミエロパチ 一の診断に際しては脊䯣くも膜瞽室の存在にも留意す る必要がある.

\section{文献}

1) Hoffman, E. P. et al.: Traumatic Arachnoidal Diverticulum Associated with Paraplegia. J. Neurosurg. 38: 81-85, 1973.

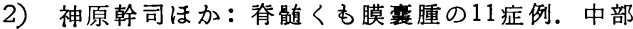
整災誌. 19: 1163-1167，1976.
3）神原幹司ほか：脊㖪くも膜秝室について。第51 回日本整形外科学会. 盛岡, 1978 .

4) Lombardi, G. et al.: Congenital Cysts of the Spinal Membranes and Roots. Brit. J. Radiology. 36: 197-205, 1963.

5）小野啓郎ほか：脊娟症状をきたした Arachnoid Cyst の 4 例. 整形外科. 21：116-121, 1970.

6) Perret, G. et al.: Diagnosis and Treatment of Intradural Cysts of the 79: 425Thoracic Spine. J. Radiology. 429, 1962.

7）杉木繁隆ほか：脊噵神経症状を呈した Spinal Arachnoid Diverticula の 1 例. 整形外科. 24 : 49-53, 1973.

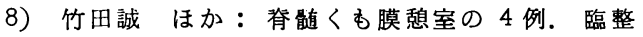
外. 10:260-267, 1975. 939: 249-254, 1966.

9) Teng, P. et al.: Spinal Arachnoid Diverticula. Brit. J. Radiology. 39: 249-254,

10）山川浩司ほ加：脊能くも膜慜室の8 例. 第26回 東日本臨床整形外科学会. 東京, 1977 .

啠 問鳥取大学整形外科 川上 俊文 くあ膜款室は胸椎部に多発しているものであるが, そのうち手術ではごれを処置したら良いのか。あし， それを決定する良い方法でもありましたらお教え下さ い.

回 答 山口大学 山口 芳英

Diverticulum が多発する場合, Diverticulum の 大きさや神経症状を参考にして，手術範囲を決定して いる. 